\title{
TINJAUAN YURIDIS TERHADAP TINDAK PIDANA PEMALSUAN UANG KERTAS RUPIAH DI INDONESIA
}

\author{
Dinda Dian Pratiwi, I Nyoman Gede Sugiartha, Luh Putu Suryani \\ Fakultas Hukum, Universitas Warmadewa, Denpasar, Bali-Indonesia \\ dindadian17@gmail.com, nyomansugiartha14@gmail.com, putusuryani099@gmail.com
}

\begin{abstract}
Abstrak
Manusia membutuhkan uang untuk mampu memenuhi kebutuhannya. Uang memiliki peranan yang sangat penting, hal ini menyebabkan sebagian orang berusaha untuk memiliki uang dengan cara yang melanggar hukum. Dengan bantuan ilmu pengetahuan dan teknologi, dapat memudahkan manusia melakukan perbuatan pemalsuan uang kertas rupiah. Tujuan penelitian ini untuk mengungkap pengaturan tindak pidana pemalsuan uang kertas rupiah di Indonesia serta sanksi pidana terhadap tindak pidana pemalsuan uang kertas rupiah di Indonesia. Tipe penelitian yaitu penelitian hukum normatif dengan pendekatan konseptual yang dituangkan secara deskriptif dengan argumentasi hukum. Dalam pengumpulan bahan hukum dilakukan dengan cara studi kepustakaan. Sumber data yang digunakan yaitu sumber bahan hukum primer, sekunder dan tersier dan dianalisis secara sistematis. Hasil penelitian mengungkapkan bahwa Pengaturan tindak pidana pemalsuan uang kertas rupiah di Indonesia diatur dalam Pasal 11 Undang-undang Nomor 7 Tahun 2011 Tentang Mata Uang mengenai Bank Indonesia merupakan lembaga yang berwenang melakukan pengelolaan uang rupiah dan Pasal 26 ayat (1) Undang- Undang Nomor 7 Tahun 2011 Tentang Mata Uang mengatur tentang larangan terhadap perbuatan pemalsuan uang rupiah. Selain itu, diatur dalam Pasal 244 KUHP yang melarang tindakan pidana pemalsuan uang, apabila dilanggar akan dikenakan sanksi sesuai ketentuan yang berlaku. Sanksi pidana terhadap tindak pidana pemalsuan uang kertas rupiah di Indonesia terdapat pada Pasal 36 ayat (1) UndangUndang Nomor 7 Tahun 2011 Tentang Mata Uang dan pada Pasal 244 KUHP.
\end{abstract}

Kata Kunci: Pemalsuan, Pidana, Uang Kertas Rupiah.

\begin{abstract}
Humans need money to be able to meet their needs. Money has a very important role, this causes some people to try to have money in a way that is against the law. With the help of science and technology, it can make it easier for humans to do counterfeiting rupiah banknotes. The purpose of this research is to reveal the regulation of the criminal act of counterfeiting rupiah banknotes in Indonesia and criminal sanctions against the criminal act of counterfeiting rupiah banknotes in Indonesia. The type of research is normative legal research with a conceptual approach that is outlined descriptively with legal arguments. The collection of legal materials is done by means of a literature research. Sources of data used are primary, secondary and tertiary sources of legal material and analyzed systematically. The results of the research reveal that the regulation of criminal acts of counterfeiting rupiah banknotes in Indonesia is regulated in Article 11 of Law Number 7 of 2011 concerning Currency concerning Bank Indonesia is an institution authorized to manage rupiah currency and Article 26 paragraph (1) of Law Number 7 The year 2011 concerning Currency regulates the prohibition against counterfeiting rupiah currency. In addition, it is regulated in Article 244 of the Criminal Code which prohibits criminal acts of counterfeiting money, if violated, sanctions will be imposed according to applicable regulations. Criminal sanctions for counterfeiting rupiah banknotes in Indonesia are contained in Article 36 paragraph (1) of Law Number 7 of 2011 concerning Currency and Article 244 of the Criminal Code.
\end{abstract}

Keywords: Counterfeiting, Criminal, Rupiah Banknotes.

\section{PENDAHULUAN}

Untuk memenuhi semua kebutuhan, manusia membutuhkan uang untuk mampu memenuhi segala kebutuhannya. Dengan adanya uang dapat mempersingkat waktu dan usaha yang diperlukan untuk melakukan perdagangan. Masyarakat mendapatkan bahwa pertukaran barang dan jasa secara langsung semakin tidak memadai dan memboroskan waktu serta tenaga, karena itu mereka mencari jalan keluar dari proses pemborosan waktu karena barter atau tukar menukar yaitu dengan menciptakan uang. Uang memiliki peranan yang sangat penting, hal ini menyebabkan sebagian orang 
berusaha untuk memiliki uang walaupun dengan cara yang melanggar aturan hukum salah satunya seperti perbuatan pemalsuan uang kertas rupiah. Tindakan ini dilakukan untuk memperoleh keuntungan, akan tetapi perbuatan itu sangat merugikan banyak pihak.

Uang sudah digunakan untuk segala keperluan sehari-hari dan merupakan suatu kebutuhan dalam menggerakan perekonomian suatu negara. Pada awalnya uang hanya digunakan sebagai alat tukar, namun seiring dengan perkembangan zaman uang tidak hanya berfungsi sebagai alat tukar, akan tetapi juga memiliki fungsi-fungsi lainnya seperti sebagai alat satuan hitung, penimbun kekayaan, dan sebagai standar pencicilan hutang. Begitu pula dengan jenis-jenis uang yang sudah demikian beragam, terutama yang digunakan sebagai alat tukar-menukar. Kejahatan pemalsuan uang kertas rupiah merupakan kejahatan yang sangat serius. Pemalsuan uang secara luas dapat menimbulkan kerugian perekonomian negara, oleh karena itu Pemerintah wajib melindungi perekonomian negara dengan memberikan hukuman yang memadai kepada pelaku sebagaimana diatur dalam peraturan perundang-undangan.

Dengan bantuan ilmu pengetahuan dan teknologi, manusia dengan mudah mampu membuat uang kertas rupiah palsu mirip dengan uang kertas rupiah yang asli. Kejahatan mengenai pemalsuan adalah kejahatan yang di dalamnya mengandung unsur keadaan ketidakbenaran atau palsu atas sesuatu (obyek). Pemalsuan yaitu suatu jenis pelanggaran terhadap kebenaran dan kepercayaan dengan tujuan memperoleh keuntungan bagi dirinya sendiri maupun bagi orang lain. Kejahatan pemalsuan uang kertas rupiah pada pokoknya ditujukan untuk memberikan perlindungan hukum kepada masyarakat terhadap kebenaran. Pada dasarnya, kejahatan mengenai pemalsuan uang dikarenakan adanya peluang mengedarkan yang besar. Jumlah transaksi tunai, selang waktu dalam melakukan transaksi dan kurang waspadanya masyarakat membuat pengedar uang palsu terpengaruh untuk melakukan pengedaran uang kertas palsu (Kusrakhmanda \& Sulchan, 2019).

Menurut Nurisman \& Monica, (2018) secara umum pemalsuan mata uang terjadi karena di latar belakangi oleh motif ekonomi, untuk memperkaya diri. Para pelaku pemalsuan maupun pelaku penyebar uang palsu melakukan transaksi yang dimana tindakan tersebut sangat merugikan orang lain. Bahkan masyarakat yang secara tidak langsung atau tidak sadar menerima uang palsu tersebut mereka pergunakannya kembali untuk melakukan transaksi dengan alasan untuk tidak merugikan diri sendiri. Dalam rangka menanggulangi permasalahan yang terjadi, maka diperlukan pengetahuan dan pemahaman yang sejalan dengan ketentuan yang ada dalam KUHP. Hal ini dikarenakan masalah tindak pidana pemalsuan yang beragam tersebut dipahami melalui satu sudut pandang tertentu, yang meliputi pengertian, ruang lingkup serta sanksi yang harus diketahui (Dewi, 2014). Dalam hal ini, menurut Rays, (2019) Kejahatan pemalsuan uang dalam hukum positif di Indonesia diatur dalam KUHPidana dari Pasal 244 KUHP sampai dengan 252 KUHP dan lebih khususnya diatur dalam UU No. 7 tahun 2011 tentang Mata Uang dimana ketentuan pidana undang-undang tersebut termuat pada pasal 33 sampai dengan pasal 41.

Maka berdasarkan penjelasan diatas, penelitian ini bertujuan untuk mengungkap pengaturan tindak pidana pemalsuan uang kertas rupiah di Indonesia serta sanksi pidana terhadap tindak pidana pemalsuan uang kertas rupiah di Indonesia.

\section{METODE PENELITIAN}

Penelitian ini menggunakan penelitian hukum normatif. Pendekatan yang digunakan yaitu pendekatan konseptual dan perundang-undangan. Pendekatan konseptual ini beranjak dari pandangan-pandangan dan doktrin-doktrin yang berkembang di dalam ilmu hukum. Pendekatan ini menjadi penting sebab pemahaman terhadap pandangan atau doktrin yang berkembang dalam ilmu hukum dapat menjadi pijakan untuk membangun argumentasi hukum ketika menyelesaikan isu hukum yang dihadapi. Pandangan atau doktrin akan memperjelas ide-ide dengan memberikan pengertian-pengertian hukum, konsep hukum, maupun asas hukum yang relevan dengan permasalahan. Pendekatan perundang-undangan ini dilakukan dengan menelaah semua peraturan perundang-undangan yang bersangkut paut dengan permasalahan (isu hukum) yang sedang dihadapi. Pendekatan perundang-undangan ini misalnya dilakukan dengan mempelajari kesesuaian antara Undang-Undang yang satu dengan Undang-Undang yang lain serta didukung dengan studi kasus atau permasalahan sebagai pemahaman terhadap fakta-fakta hukum yang telah terjadi. Dalam pengumpulan bahan hukum dilakukan dengan cara studi kepustakaan, yang diawali dengan menginventarisasi bahan hukum yang terkait dilanjutkan dengan memilah-milah atau mengklasifikasi 
bahan hukum dan disusun secara sistematis kemudian dilakukan teknik penelitian yaitu dengan mengutip, meringkas, serta memberi ulasan sesuai dengan pokok pembahasan. Sumber bahan hukum yang digunakan adalah bahan hukum primer yang didapat dengan menganalisis peraturan perundangundangan, risalah resmi, dan beberapa keputusan-keputusan yang menyangkut dengan judul penelitian ini. Bahan hukum sekunder didapat dari menganalisis buku-buku,jurnal-jumal dan hasilhasil penelitian terdahulu yang memiliki keterkaitan dengan judul penulisan ini. Dan bahan hukum tersier yang dapat menunjang bahan hukum primer dan sekunder seperti kamus-kamus hukum dan tulisan yang dapat diakses melalui internet. Bahan hukum yang telah terkumpul selanjutnya dianalisis secara sistematis dengan menggunakan argumentasi hukum berdasarkan logika hukum deduktif dan dituangkan secara deskriptif yaitu dengan menguraikan, menjelaskan dan menggambarkan sesuai dengan permasalahan yang erat kaitannya dengan penelitian ini.

\section{HASIL DAN PEMBAHASAN}

\section{Pengaturan Tindak Pidana Pemalsuan Uang Kertas Rupiah di Indonesia}

Di dalam masyarakat, semua kegiatan-kegiatan ekonomi akan memerlukan uang guna memenuhi kebutuhannya. Keberadaan uang di Indonesia telah memudahkan manusia dalam melakukan kegiatan transaksi barang dan jasa. Keberadaan uang memiliki peranan penting dalam kehidupan manusia, karena dengan menggunakan uang manusia dapat memenuhi kebutuhan hidup sehari-hari. Berdasarkan Pasal 2 ayat (2) Undang-Undang Republik Indonesia Nomor 23 Tahun 1999 Tentang Bank Indonesia, menyatakan bahwa uang rupiah adalah alat pembayaran yang sah di wilayah Negara Republik Indonesia.

Definisi uang menurut Iswardono adalah sesuatu yang secara umum diterima di dalam pembayaran untuk pembelian barang-barang dan jasa-jasa serta untuk pembayaran utang-utang (Iswardono, 1996). Robertson menyatakan bahwa uang adalah segala sesuatu yang umum diterima sebagai pembayaran untuk benda-benda atau untuk melunasi kewajiban-kewajiban lain dalam dunia usaha (Winardi, 1988). Definisi uang menurut Mochamad Anwar yaitu uang yang dibuat dari kertas yang dikeluarkan oleh Pemerintah. Uang kertas rupiah merupakan uang yang terbuat dari kertas dengan bahan bakunya adalah penggunaan serat kapas. Berdasarkan penjelasan tersebut, dapat diketahui bahwa yang dimaksud dengan uang kertas rupiah adalah alat pembayaran yang sah di wilayah Negara Republik Indonesia yang terbuat dari kertas yang digunakan sebagai pembayaran pembelian barang dan jasa serta membayar kewajiban lainnya.

Menurut Wirjono Prodjodikoro pemalsuan adalah suatu perbuatan yang disengaja meniru suatu karya orang lain untuk tujuan tertentu tanpa ijin yang bersangkutan (illegal) atau melanggar hak cipta orang lain (Wirjono, 2003). Kejahatan pemalsuan uang kertas rupiah adalah berupa penyerangan terhadap kepentingan hukum atas kepercayaan terhadap uang sebagai alat pembayaran yang sah. Sebagai alat pembayaran, kepercayaan terhadap uang harus dijamin. Dalam hal ini, pemalsuan uang kertas rupiah adalah membuat benda uang kertas rupiah yang menyerupai atau mirip dengan uang kertas rupiah yang asli. Pelaku pemalsuan uang kertas rupiah biasanya tidak dilakukan seorang diri dan memerlukan perencanaan terlebih dahulu sebelum melakukan perbuatan tersebut.

Perbuatan pemalsuan dapat digolongkan dalam golongan kejahatan penipuan. Perbuatan pemalsuan tergolong kelompok kejahatan penipuan apabila seseorang memberikan gambaran tentang sesuatu keadaan atas barang seakan-akan asli atau benar, sedangkan sesungguhnya keaslian atau kebenaran tersebut tidak dimilikinya. Karena gambaran ini orang lain terpedaya dan mempercayai bahwa keadaan yang digambarkan atas barang tersebut adalah benar atau asli.

Tindak pidana adalah perbuatan yang dilarang oleh suatu aturan hukum, larangan mana disertai ancaman (sanksi) yang berupa pidana tertentu bagi barangsiapa melanggar larangan tersebut (Jonaedi, 2014). Menurut Wirjono Prodjodikoro, menyatakan bahwa tindak pidana itu adalah suatu perbuatan yang pelakunya dapat dikenakan hukuman pidana (Adami, 2010). Tindak pidana adalah perbuatan yang melanggar larangan yang diatur oleh aturan hukum yang diancam dengan sanksi pidana. Yang dimaksud dengan tindak pidana pemalsuan uang kertas rupiah adalah suatu perbuatan manusia yang melanggar aturan hukum dimana dalam hal ini membuat uang kertas rupiah palsu yang dilakukan dengan sengaja dengan adanya maksud tertentu didalamnya yang pelakunya dapat dikenakan hukuman pidana. 
Tindak pidana pemalsuan uang kertas rupiah dilakukan dengan adanya suatu kesengajaan untuk memperoleh sesuatu keuntungan yang diinginkan. Kesengajaan adalah kehendak yang ditujukan untuk melakukan perbuatan, dalam arti bahwa untuk mewujudkan perbuatan itu memang telah dikehendaki sebelum seseorang itu sungguh-sungguh berbuat. Keaslian uang kertas rupiah dapat diketahui pada ciri-ciri rupiah yang terdapat pada uang tersebut. Pemeriksaan keaslian uang kertas rupiah dapat dilakukan dengan menggunakan alat khusus pendeteksi uang yaitu dengan sinar ultraviolet dan kaca pembesar. Selain itu juga, terdapat tiga cara untuk mengetahui keaslian uang kertas rupiah tanpa menggunakan suatu alat, yaitu dengan cara dilihat, diraba, dan diterawang. Dengan mengenali keaslian uang kertas rupiah, dapat membantu masyarakat untuk mengetahui dan mengenali ciri-ciri keaslian dari suatu uang kertas rupiah yang telah dimiliki atau yang baru diterima. Apabila masyarakat dapat mengenali keaslian dari uang kertas rupiah, maka masyarakat dapat membedakan antara uang kertas rupiah yang asli dengan uang kertas rupiah palsu.

Terkait dengan tindak pidana pemalsuan uang kertas rupiah diatur di dalam Undang-Undang Nomor 7 Tahun 2011 Tentang Mata Uang dan Kitab Undang-Undang Hukum Pidana (KUHP). Uang kertas rupiah digunakan sebagai alat pembayaran yang sah dan berlaku pada saat peredarannya, dalam hal ini sah memiliki arti yang menurut peraturan dikeluarkan oleh lembaga yang berwenang. Bank Indonesia merupakan satu-satunya lembaga yang berwenang untuk menerbitkan serta mengedarkan uang kertas rupiah di wilayah Negara Kesatuan Republik Indonesia, hal ini dapat dilihat dalam Pasal 11 Undang-Undang Nomor 7 Tahun 2011 Tentang Mata Uang. Selain itu, terdapat pengaturan mengenai larangan terhadap perbuatan pemalsuan uang rupiah yaitu terdapat dalam ketentuan Pasal 26 ayat (1) Undang-Undang Nomor 7 Tahun 2011 Tentang Mata Uang, bagi yang melanggar akan dikenakan sanksi sesuai ketentuan yang berlaku sebagaimana ketentuan perundang-undangan yang berlaku. Pemalsuan uang kertas rupiah juga diatur dalam Kitab UndangUndang Hukum Pidana (KUHP) pada Bab X Buku II mengenai kejahatan. Pengaturan mengenai perbuatan pemalsuan terhadap uang di dalam Kitab Undang-Undang Hukum Pidana (KUHP) diatur dalam Pasal 244 KUHP yang melarang tindakan pidana pemalsuan uang dan apabila dilanggar akan dikenakan sanksi sesuai ketentuan yang berlaku sebagaimana ketentuan yang berlaku.

\section{Sanksi Pidana Terhadap Tindak Pidana Pemalsuan Uang Kertas Rupiah di Indonesia}

Pada kenyataannya dalam masyarakat ada sejumlah perbuatan- perbuatan yang pada dasarnya sudah mengandung sifat terlarang atau melawan hukum yang pada pembuatnya patut dijatuhi pidana. Adanya suatu tindak pidana merupakan alasan bagi negara dalam menggunakan haknya untuk memberlakukan hukum pidana melalui alat-alat perlengkapannya, seperti Kepolisian, Kejaksaan, ataupun Pengadilan. Hak negara tersebut adalah hak untuk melakukan penuntutan, mengadili, ataupun menjatuhkan pidana terhadap seseorang yang diduga melakukan suatu tindak pidana.

Penjatuhan sanksi pidana hanya ditujukan dalam hal tidak ada upaya lain yang lebih layak di samping tingkat kerugian yang dialami oleh masyarakat begitu besar dan tidak dapat dipulihkan kembali (Ali, 2015). Sebagai alat pembayaran, kepercayaan terhadap keaslian dan kebenaran terhadap uang harus mendapatkan perlindungan hukum. Sanksi atau hukuman bersifat penderitaan, karena hukuman itu dimaksudkan sebagai hukuman terhadap pelanggaran yang dilakukan oleh seseorang terhadap kepentingan hukum yang dilindungi oleh hukum pidana dengan harapan untuk dapat memberikan efek jera terhadap pelaku tindak pidana serta mengurangi terjadinya tindak pidana pemalsuan terhadap uang kertas rupiah di Indonesia.

Terkait sanksi pidana terhadap tindak pidana pemalsuan uang kertas rupiah di Indonesia terdapat pada ketentuan Pasal 36 ayat (1) Undang-Undang Nomor 7 Tahun 2011 Tentang Mata Uang yang memberikan sanksi pidana dengan pidana penjara paling lama 10 (sepuluh) tahun dan pidana denda paling banyak Rp 10.000.000.000,00 (sepuluh miliar rupiah) bagi yang melanggar ketentuan tersebut. Selain itu, mengenai sanksi pidana terhadap tindak pidana pemalsuan uang kertas rupiah di Indonesia terdapat pada ketentuan Pasal 244 Kitab Undang-Undang Hukum Pidana (KUHP) yang memberikan sanksi pidana dengan pidana penjara paling lama lima belas tahun bagi yang melanggar ketentuan tersebut. 


\section{SIMPULAN DAN SARAN}

\section{Simpulan}

Berdasarkan pemaparan pada bab-bab sebelumnya, maka penulis menyampaikan simpulan untuk menjawab dua pokok permasalahan dalam penelitian ini adalah Pengaturan tindak pidana pemalsuan uang kertas rupiah di Indonesia yaitu diatur di dalam Undang-Undang Nomor 7 Tahun 2011 Tentang Mata Uang dan di dalam Kitab Undang-Undang Hukum Pidana (KUHP). Berdasarkan ketentuan Undang-Undang Nomor 7 Tahun 2011 Tentang Mata Uang diatur di dalam Pasal 11 dan Pasal 26 ayat (1) Undang-Undang Nomor 7 Tahun 2011 Tentang Mata Uang. Selain itu, juga diatur mengenai tindak pidana pemalsuan uang kertas rupiah pada Bab X Buku II mengenai kejahatan dalam Pasal 244 Kitab Undang-Undang Hukum Pidana (KUHP). Adapun sanksi pidana terhadap tindak pidana pemalsuan uang kertas rupiah di Indonesia terdapat pada ketentuan Undang-Undang Nomor 7 Tahun 2011 Tentang Mata Uang dan terdapat pada ketentuan Kitab Undang-Undang Hukum Pidana (KUHP). Berdasarkan ketentuan Pasal 36 ayat (1) Undang-Undang Nomor 7 Tahun 2011 Tentang Mata Uang menjelaskan bahwa setiap orang, baik secara individu maupun kelompok yang memalsukan uang rupiah akan dipidana dengan pidana penjara paling lama 10 (sepuluh) tahun dan pidana denda paling banyak Rp 10.000.000.000,00 (sepuluh miliar rupiah). Selain itu, berdasarkan ketentuan Pasal 244 Kitab Undang-Undang Hukum Pidana (KUHP) menjelaskan bahwa barang siapa, baik secara individu maupun kelompok yang membuat uang palsu dengan maksud untuk mengedarkannya akan dipidana dengan pidana penjara yaitu paling lama lima belas tahun.

\section{Saran}

Bagi Pemerintah, pengaturan mengenai tindak pidana pemalsuan uang kertas rupiah di Indonesia yang terdapat dalam ketentuan Pasal 11 dan Pasal 26 ayat (1) Undang-Undang Nomor 7 Tahun 2011 Tentang Mata Uang serta dalam Pasal 244 Kitab Undang-Undang Hukum Pidana (KUHP) adalah sudah tepat bagi pelaku dan korban, karena di dalamnya secara jelas telah diatur mengenai pengelolaan uang dan larangan terhadap perbuatan pemalsuan uang dengan ancaman sanksi yang tegas bagi pelakunya. Bagi masyarakat, lebih teliti dalam memeriksa keaslian uang kertas rupiah yang diterima atau didapat sehingga dapat mempercepat diketahui adanya uang palsu dan segera melaporkan kepada penegak hukum. Sanksi yang telah ada harus disertai pemantauan yang tepat oleh penegak hukum untuk memastikan peredaran uang palsu tidak merugikan masyarakat dan pelaku dikenakan sanksi sesuai ketentuan yang berlaku.

\section{DAFTAR PUSTAKA}

Adami, C. (2010). Pelajaran Hukum Pidana. PT RajaGrafindo Persada, Jakarta.

Ali, Z. (2015). Menuju Pembaruan Hukum Pidana. Sinar Grafika, Jakarta.

Dewi, E. (2014). Penegakan Hukum Terhadap Pelaku Tindak Pidana Pemalsuan Uang dan Pengedar

Uang Palsu di Kota Bandar Lampung. Keadilan Progresif, 5(1), 71-87.

Iswardono. (1996). Uang dan Bank. BPFE, Yogyakarta.

Jonaedi, E. (2014). Cepat \& Mudah Memahami Hukum Pidana. Kencana, Jakarta.

Kusrakhmanda, R., \& Sulchan, A. (2019). Penegakan Hukum Terhadap Kejahatan Pemalsuan Uang

Kertas Rupiah di Kota Semarang (Studi Kasus di Pengadilan Negri Semarang). Konferensi Ilmiah Mahasiswa UNISSULA (KIMU) 2, 164-180.

Nurisman, E., \& Monica, S. (2018). Tinjauan Yuridis terhadap Pelaku Tindak Pidana Penyebaran Uang Palsu. Journal of Judicial Review, 20(1), 124-134.

Rays, H. M. I. (2019). Kajian Normatif Terhadap Kejahatan Pemalsuan Uang di Indonesia. Jurnal Yustisiabel, 3(1), 25-46.

Winardi. (1988). Pengantar Ilmu Ekonomi. Tarsito, Bandung.

Wirjono, P. (2003). Tindak-Tindak Pidana Tertentu di Indonesia. PT Refika Aditama, Bandung. 